\title{
A Review Article on Value Chain Analysis of Vegetable Sub-sector in Nepal
}

\author{
Manoj Sharma* \\ Department of Agricultural Economics and Agribusiness Management, Agriculture and Forestry University, Nepal \\ *Corresponding Author: Manoj Sharma, Department of Agricultural Economics and Agribusiness Management, Agriculture and Forestry \\ University, Nepal.
}

Received: June 04, 2019; Published: August 06, 2019

DOI: 10.31080/ASAG.2019.03.0598

\begin{abstract}
The paper is aimed to review the various research papers related to value chain analysis of vegetable subsector. Many numbers of manuals, guidelines, research articles and thesis were collected using Google scholar to study about value chain approach and eight research papers specialized to value chain analysis on vegetable production in Nepal were selected for review. While reviewing, this paper has initially mentioned the study area, methodology and key findings, and then has critically reviewed the coordination between the research objectives, problems and their findings. It has also pointed out the research gaps that were lacking. However, the commons found in all these papers were identification of primary and secondary actors on value chain of vegetables, market channels, market margin and key problems faced by actors on marketing side with their recommendations. Most of the papers had collected data through survey using questionnaire and checklists for households, traders and consumers. Finally, the paper has concluded that situation of value chain on vegetable in Nepal is not satisfactory. The producer's share on consumer price were very low than expected and prices are strongly influenced by market syndicates. Therefore, government policy should focus on quality input supply for vegetable producers, improvements on production and marketing to increase producer's share on consumer price and to reduce marketing cost.
\end{abstract}

Keywords: Market Channel; Market Margin; Supply Chain; Value Chain; Vegetables

\section{Introduction}

\section{Background of the study}

Value chain is full range of activities to deliver agricultural commodities through the different phases of production (involving a combination of physical transformation and the input of various producer services), transformation and delivery to final consumers [1]. The concept of value chain was first introduced by Michael Porters in his book named "Competitive Advantage: Creating and Sustaining Superior Performance" in 1980s. He has considered value chain as basic tool for analyzing the source of competitive advantage [2].

Value chain analysis is conducted for a variety of purposes. The primary purpose of value chain analysis is to understand the rea- sons for inefficiencies in the chain, and identify potential leverage points for improving the performance of the chain, using both qualitative and quantitative data. The value chain framework seeks to overcome the constraints of market channels by identifying different entry-points and linkages that small and medium enterprises can leverage in a given production or supply chain [3]. The value chain concept also entails the addition of value as the commodities are transferred from the different stage of processing units and actors along the route of producer to consumers. A value chain, therefore, incorporates productive transformation and value addition at each stage of the value chain. Value addition is the result of different activities like sorting, cleaning, processing, packaging, transporting, grading etc. The value of product changes along different actors, transaction cost incurred and some form of value is 
added [4]. So, the promotion of value chains in agribusiness aims to improve the competitiveness of agriculture in national and international markets and to generate greater value added within the country.

In Nepal, ADS (2015-2035) has prioritized the need to accelerate the development of value chain by creating Value Chain Development Program (VADEP) under "ADS flagship programs." A total of 48 value chains across the four major sectors i.e. crops (32 commodities/products), livestock (11), fisheries (2), and forestry (NTFP/MAP - 3) were assessed and prioritized by establishing National Value Chain Development Program and clearly mentioned to improve productivity for smallholder farmers, postharvest operations and marketing of these commodities and policies, regulatory framework and institutions for agriculture sector [5].

\section{Objectives}

In most of research papers, value chain approach in agriculture sector is used to understand the competitive challenges, identification of relationships and coordination mechanisms, and finally to know how chain actors deal with powers and who governs or influences the chain. So, this paper is primarily aimed to review the research papers and articles and to summarize their conclusions with critical evaluation and gaps to related sectors. The specific objectives of the article review are:

- To understand the concept and usefulness of value chain analysis in agriculture sector.

- $\quad$ To evaluate the articles and papers critically to find out the research situation and gaps on value chain analysis of vegetable subsector.

- To broaden the knowledge about value addition, marketing channels and major constraints of market.

\section{Concepts and Literature Review}

The section has discussed on concepts, definitions, methodologies and usefulness of agricultural value chain.

Definitions and concepts in value chain analysis

The concept of agricultural value chain includes the full range of activities and participants involved in moving agricultural products from input suppliers to farmers' fields and ultimately to consumers' table. Each stakeholder or process in the chain has a link to the next in order to form a viable chain [6].
Porter [2] indicates that value can be created by differentiation along every step of the value chain, through activities resulting in products and services that lower buyers' costs or raise buyers' performance. In much of the food production and distribution value chain, the value creation process has focused on commodities with relatively generic characteristics, creating relatively small profit margins.

Bammann [7] has identified three important levels of value chain, which are value chain actors, supporters and influencers. Actors are those who directly deal with the products, i.e. produce, process, trade and own them, while value chain supporters never directly deal with the product, but whose services add value to the product. And, finally, value chain influencers are regulatory framework, policies, infrastructures, etc.

Value chains encompass a set of interdependent organizations, and associated institutions, resources, actors and activities involved in input supply, production, processing, and distribution of a commodity. In other words, a value chain can be viewed as a set of actors and activities, and organizations and the rules governing those activities.

Supply Chain is a sequence of (decision making and execution) processes and (material, information and money) flows that aim to meet final customer requirements, that take place within and between different stages along a continuum, from production to final consumption [8].

Market chain is a sequence generally drawn for one commodity and is usually vertical, which illustrate the points within the market system where production, transformation, distribution and consumption of a commodity take place. It includes all levels of the market (assembly, wholesale and retail) and actors that have a role in the distribution and transformation of a commodity [8].

The marketing margin or the farm-to-retail price spread is the difference between the farm value and the retail price. It represents payments for all assembling, processing, transporting, and retailing charges added to the value of farm products after they leave the farm [9].

The marketing efficiency is measured in terms of price integration of markets. It is simply a input-output ratio, such as labor used 
per unit of output or capital investment per unit of output [10]. It is of two type viz. technical efficiency and pricing efficiency.

Though theoretically there are differences between these two surpluses i.e. marketed surplus and marketable surplus, they are often used as interchangeably. The marketed surplus refers to amount actually taken to market where as the marketable surplus is the output net of seed, payments in kind, and consumption at source [11].

Value addition is one aspect of marketing that deals with practices that change or transform a primary product into goods that have additional value. Values adding activities based on their simplicity and difficulties. The simplest are washing, cleaning, grading, bulking and storage; these activities are conducted by the control of farmers. And the complicated are ginning, roasting, refrigerating, milling, cutting, mixing, dehydration, cooking and packaging. These activities are generally undertaken by specialist market chain actors or service providers [12].

Methodology for value chain analysis

Kaplinsky and Morris [1] outlined the methodology for undertaking value chain research into eight headlines which are discussed below:

- The point of entry for value chain analysis: The point of entry means the subject of enquiry in chains with their linkage and activities. There are twelve possible points of entry which are the global distribution of income, retailers, independent buyers, key producers, sub-suppliers, commodity producers, agricultural producers, small farms and firms, informal economy producers and traders, women, children and other marginalized and exploited groups.

- Mapping value chain: Mapping of value chain clearly show the logical sequences of activities along with their key actors. The iterative process of value chain mapping involves two stages. First is initial map showing the flows and structures of chain involving key actors from input supply to consumers and second stage is quantifying the map [13].

- Product segments and Critical Success Factors in final markets: Product differentiation and Critical Success Factors (CSFs) are two most important components of contemporary market which need to be analyzed to understand the value chain dynamics. Generally, in low income final markets, price will be a relatively important
CSF, but it will not be unique. Customers will also require quality, differentiation and branding.

- How producers access final markets: There are buying institutions like wholesaler firms, retails, independent buyers and large firm which link the producers to markets. The dynamics of buying function of these institutions characterize the value chain as buyer driven or producer driven.

- Benchmarking production efficiency: There are many market drivers like cost effectiveness, quality, lead times (value chain flexibility), capacity to change (human resources management) and innovative capacity which require operational practices and will be reflected in performance outcomes. These performance outcomes and practices can be benchmarked, against internal operations over time, and against competitors.

- Governance of value chains: Governance is simply the term of coordination for value chain which highlights power relations in the chain and the institutions which mould and wield this power. There are indicators like the share of chain sales, share of chain value added, share of chain profits, relative rate of profit, share of chain buying power, control over a key technology and distinctive competence and holder of chain "market identity" (e.g. brand name) which help to identify the key governor of value chain.

- Upgrading in value chains: Upgrading is a process of adopting innovation a process which recognizes relative endowments and the existence of rents. There are four forms of upgrading process upgrading, product upgrading, functional upgrading and chain or inter-sectorial upgrading.

- Distributional issues: The distributional issues contains both power and income components. The issues includes the distribution of returns from production chains, dimension of value chain (global, national and local), measurement of profitability and circumstances for value addition and profit as measure of distribution outcomes.

- According to GTZ [14] the value chain map represents the micro and meso levels of value chain but does not necessarily include the macro level. In value chain, micro level includes the VC operators and operation services provider, whereas meso level includes service support providers like rural banks, agricultural government institutions and macro level includes institution and public bodies that create business enabling environment.

\section{Methodology}

This paper collected the information and data about value chain based on secondary sources. Different manuals, guidelines, re- 
search papers and articles were gathered through a web search using Google and Google Scholar. Key words used in the search were value chain manuals, value chain guidelines, research on value chain analysis, market chain analysis and value chain handbooks. Similarly, many reports and articles were also taken from websites of MOAD, PACT, HVAP etc. and thesis of Universities like AFU, TU etc.

\section{Article reviewed}

The previous research activities about agricultural value chain and marketing on different agricultural commodities are discussed in this topic. So this part has been made to critically review the past research activities for better understanding of this subject.

Regmi [15] has studied to analyze the value chain of vegetables in Palpa district of Nepal and collected data by interviewing with value chain actors (Input suppliers, Farmers, Traders and Consumers), focus group discussion and meeting with government bodies. From his research, he identified seven different vegetable marketing channels. The study has revealed that tomato, green chilly and the cauliflower are the high value and high market demanded commodity in Palpa so there is higher scope for the cultivation of these crops mainly in rainy season. Poor linkage and coordination among value chain actors (farmer, whole sellers, retailers etc.), problem of trust between farmers and MPC and lack of proper operation guidelines were the higher ranked constraints of marketing. The research has more focused on opportunities and constraint of vegetable farmers, but has not clearly discussed on market margins and producers share on consumer price.

HVAP [16] had studied on value chain analysis of offseason vegetables (OSV) along the three road corridors - Chhinchu-Jajarkot, Surkhet-Dailekh and Surkhet-Jumla and found that the rate of price margin at these each stage of offseason vegetable production was significantly different. The market margin for cabbage was found to be highest having $150 \%$ followed by cauliflower, green pea and tomato having market margin 113\%, 111\% and 94\% respectively. The gross margin was found higher in farm gate and retail level than in collection and wholesale levels. In collection centers and wholesale markets, traders take about $15 \%$ margin. The study further found the various value chain constraints for higher market margins and their market based solutions. However, the report is silent to input supply sides. The HVAP districts have lots of problems with respect to inputs like unavailability of fertilizers, low quality seeds, irrigation facilities etc. which have not explored.
USAID [3] explored value chain development of high value vegetables for conflict affected environments through guided case studies. A general survey template was conducted for interviewing the various stakeholders. The districts and Village Development Committees (VDCs) were chosen for field interviews and observations based on the impact of the conflict. The study found that there are very high opportunities to upgrade mountain value chain of vegetables due to its comparative advantages but a set of constraints like unstable political situation, poor marketing facility, tariff and non-tariff barriers to trade and lack of infrastructures are discouraging the upgrading of value chain. However, the farmers of SIMI (Smallholder Irrigation Marketing Initiative) and UJYALO communities adopting the value chain approach for longer period of time appeared to have higher incomes and profit margins.

The study had used the limited procedures for data collection while analyzing value chain analysis and focused only for conflict affected procedures. However, the case study has concluded a value chain approach as tailor machine for improving Nepal's conflict circumstances and agricultural conditions through increasing the livelihoods and incomes of conflict-affected rural populations.

Again, USAID [3] has also studied about value chain/market analysis of off-season vegetable and again found that the production and marketing of off-seasonal vegetables is very popular in Nepal. But various constraints like input unavailability, limited collection centers, unreliable market information, and lack of proper post-handling and transportation were hindrances of establishment of off-seasonal vegetable market. The study also recommended the short-term and long-term intervention strategies for competitiveness of this subsector.

Devkota, Dhakal, Dutta, and Gautam [17] assessed fruit and vegetable losses at major wholesale markets in Nepal. For this, they carried out structured questionnaire survey at Kathmandu, Pokhara and Narayangadh and found that 22 percent due to inappropriate packaging and poor handling and 11 percent due to poor quality produce are main reasons behind the post harvest loss of vegetable in Nepal. Similarly, unavailability of fertilizers at right time, lack of cold storage facility and inappropriate packaging facility had significant effect on the loss of the produce.

Pokhrel [18] has explored the market channels, farm profits and shares on wholesale prices explained through cost-benefit assess-

Citation: Manoj Sharma. “A Review Article on Value Chain Analysis of Vegetable Sub-sector in Nepal”. Acta Scientific Agriculture 3.9 (2019): 15-20. 
ments on vegetable pockets of Kabhrepalanchok, Sindhupalchowk and Kaski districts. In his study, he found that doke and collectors were major intermediaries to deliver the vegetables representing 21 and 59 percent respectively from farm production sites to consumers in Kaski. Similarly, local and road head markets as major intermediate markets for transfer of vegetables from farmer field to consumers representing 43 and 55 percent respectively in Sindupalchowk and Kabreplanchowk district.

Poudel [19] studied to identify structural causes of marketing margin for off-season vegetables value chain in a part of SurkhetDailekh road corridor. The primary data were collected by interviewing to selected farmers, collectors, wholesalers with the help of questionnaires. The research study found that the profit margin kept by value chain actors in tomato, cauliflower and cabbage were 31, 28 and 44 percent respectively. Again, the marketing margin found doubled in all types of off-season vegetables value chain. The share of postharvest loss observed in tomato and cauliflower were 42 and 37 percent respectively. The study also showed post-harvest loss found more prominent factor than profit margin kept by value chain actors for contributing high gap in marketing margin of off-season vegetables value chain. But, the research has not included the study of bottlenecks of value chain and market channel.

Chaudhary [20] analyzed the tomato marketing system in Lalitpur district, Nepal and collected data semi-structured interview from grower farmers, wholesalers and retailers. The study was intended to identify marketing channels, to estimate gross margin, marketing margin and producer share, to find out the situation of market information and to identify constraints related to production and marketing of vegetables, especially tomato. Gross margin analysis showed that tomato growing is an important option for smallholder farmers in contributing family income. The producer's share is highest among all actors in the value chain [21-27].

\section{Conclusion}

Vegetable farming is one of the potential sources of income and reliable means for the reduction of poverty and malnutrition persisting over Nepal. It plays a positive role for contributing better livelihood by providing regular employment and income to the marginal farmers of the country and their family members throughout the year. However, previous study indicated that the product marketing is imperfect due to malpractices of intermedi- aries, poor marketing system, inadequate and improper policies and other reasons. Similarly, the marketing of vegetables is characterized by seasonal gluts and shortages which in turn affect the marketing behaviors of farmers, traders and consumers. For this, value chain approach is considered as tool for study the constraints of vegetable production from input supply to consumer. The study also provides information on the determinants of vegetables supply to the market and identifies opportunities and constraints of vegetables value chain. So, these information helps to way forward for formation of polices and strategies concerned for increasing per capita income of small holding farmers.

\section{Bibliography}

1. Kaplinsky Raphael and Mike Morris. A handbook for value chain research. Ottawa: IRDC (2001).

2. Porter Michael E. Competitive Advantage: Creating and Sustaining Superior Performance. New York: The Free Press (1985).

3. USAID. A comparative case study of high-value vegetable value chains in Nepal: Guided case studies in value chain development for conflict-affected environments. Washington DC: United States Agency for International Agency (2008).

4. Anandajayasekeram Poniah and Berhanu Gebremedhin. "Integrating innovation systems perspective and value chain analysis in agricultural research for development: Implications and challenges". International Livestock Research Institute (ILRI) (2009).

5. MOAD. Agriculture Development Strategy (ADS): 2015-2035. Kathmandu: Ministry of Agriculture Development (2015).

6. Miller C and L Jones. Agricultural value chain finance-Tools and lessons. Rome: Food and Agriculture Organization (FAO) (2010).

7. Bammann Heiko. "Participatory value chain analysis for improved farmer incomes, employment opportunities and food security". Pacific Economic Bulletin 22.3 (2007): 113-125.

8. FAO. Agro-industrial supply chain management: concepts and applications. Rome: Food and Agriculture Organization (2007).

9. Elitzak Howard. "Food Cost Review, 1950-97" (1999). 
10. Bressler Raymond G and Richard A King. Markets, prices, and interregional trade. New York: Wiley (1970).

11. Nadkarni MV. Marketable surplus and market dependence: A study of a millet region. Allied Publishers Private Ltd (1980).

12. Muluken Marye. Value chain analysis of fruits for Debub Bench Woreda, Bench Maji Zone, SNNPR (master's thesis). Mekelle, Ethiopia: Mekelle University (2014).

13. UNIDO. Agro-value chain analysis and development: The UNIDO Approach. Vienna: United Nations Industrial Development Organization (2009).

14. GTZ. Value chain analysis and "making markets work for the poor" (m4p) - Poverty reduction through value chain promotion. Eschborn: German Technical Cooperation (2006).

15. Regmi Khim Raj. "Value chain analysis of vegetables in Palpa district of Nepal”. Economic Affairs 58.2 (2013): 135-146.

16. HVAP. A report on value chain analysis of offseason vegetables (OSV). Surkhet: MOAD, High Value Agriculture Project (HVAP) in Hill and Mountain Areas (2011).

17. Devkota AR., et al. "Assessment of fruit and vegetable losses at major wholesale markets in Nepal". International Journal of Applied Sciences and Biotechnology 2 (2014): 559-562.

18. Pokhrel Deepak Mani. "Comparision of farm production and marketing cost and benefits". The Journal of Agriculture and Environment 11 (2010): 10-25.

19. Poudel Prabin. "Marketing margin assesment of offseason vegetables value chain in Serkhet Dailekh road corridor". The Journal of Agriculture and Environment 13 (2012): 27-31.

20. Chaudhary Kalash Ram. "Analysis of tomato marketing system in Lalitpur district, Nepal". Msc. Thesis. Van Hall Larenstein University of Applied Sciences (2010).

21. Ayele Gezahegn., et al. "Constraints of vegetables value chain in ethiopia: a gender perspective". International Journal of Advanced Research in Management and Social Sciences (2014): 45-71.

22. Market assessment and analysis: Learner's notes. Rome: Food and Agriculture Organization (2008).

23. Value links manual: The methodology of value chain promotion. Eschborn: German Technical Cooperation (2007).
24. Hailu A. Value chain analysis of vegetables: The case of Ejere District, West Shoa zone, Oromia National Regional State of Ethiopia. Msc. Thesis. Haramaya University (2016).

25. Kapilnsky R. "Globalization and unequalization: what can be learned from value chain analysis". Journal of Development Studies 37.2 (2010): 117-146.

26. Value chain/market analysis of the off-season vegetable subsector in Nepal. Nepal economic agriculture, and trade activity. Kathmandu: United States Agency for International Development (2011).

27. Van der Vorst., et al. Agro-industrial supply chain management: concepts and applications. Rome: FAO (2007).

\section{Volume 3 Issue 9 September 2019}

(C) All rights are reserved by Manoj Sharma. 